\title{
Object Co-Segmentation using Image Processing
}

\author{
Balaji. S, John paul Praveen. A, B. Hemalatha
}

\begin{abstract}
Given a lot of pictures that contain objects from a typical classification, object co-division goes for naturally finding and sectioning such regular articles from each picture. In the proposed structure, we initially present the idea of association foundation and use it to improve the power for smothering the picture foundations contained by the given picture gatherings. At that point, we likewise debilitate the necessity for the solid earlier learning by utilizing the foundation earlier. For the feeble foundation earlier, the model which is called the MR-SGS model is utilized. This is characterized as complex positioning with a self-learned diagram structure.it can derive the reasonable chart structures as opposed to fixing diagram structures in a given plan.

Keywords: Picture division, Image co-division, managed learning, Interactive learning, PC vision
\end{abstract}

\section{INTRODUCTION}

Article co-division goes for finding and dividing the co-happening objects from the given arrangement of pertinent pictures utilizing Manifold Ranking-Self educated Graph Structure. Dissimilar to the single picture object division techniques which just depend on the earlier or low-level prompts inside one single picture. Article co-division techniques need further endeavor to the correspondence relationship among the numerous related images.in late days over PC vision, the low dimension picture handling is a huge issue. Among them, picture division is one of the issues. Which is utilized for breaking down the pictures? Presently multi day full misuse of steady data among the arrangement of pictures is the greatest test and research hotspot. For that issue picture, co-division is a pattern nowadays. Social sites like facebook and so forth., we are sharing billions of photographs and among them, the misuse of vision is occurring. Also, for that, the forefront of pictures are framed and shaped like a 3D object. By utilizing object co-division it is exceptionally simple to concentrate forefront object from all arrangement of pictures [1-8].

\section{EXISTING SYSTEM}

Looking at the forefront shading histograms using Gabor FiltersUsing Shape formats and Part identifiers. One of the techniques is performing pixel-level division. Furthermore, some are focused on improving the worldwide vitality term and relating enhancement methods.in that strategy by including of frontal area likeness imperative into conventional MRF based division strategies the item co-division is

\section{Revised Manuscript Received on August 22, 2019.}

Balaji. S, Department of Electronics and Communication Engineering, Bharath Institute of Higher Education and Research, Chennai, Tamilnadu, India.

John paul Praveen A, Department of Electronics and Communication Engineering, Bharath Institute of Higher Education and Research, Chennai, Tamilnadu, India.

B. Hemalatha, Department of Electronics and Communication Engineering, Bharath Institute of Higher Education and Research, Chennai, Tamilnadu, India. happened. Later on that a few strategies are raised by utilizing the diagram cut methods.

Disadvantages Of Existing System:

Fails to explore the dis-criminality between the common objects and the image backgrounds Robustness is not achieved cannot handle the images with large appearance variation. And reflection if robustness is explored.

\section{PROPOSED SYSTEM}

In the proposed framework another strategy or model is the MR-SGS model, which has oneself learning ability to adjust the chart structure in an information-driven manner. by this, we can section the numerous items from a lot of pictures with the division of both forefront and foundation structures. On the off chance that there is no adjustment in pixel marks, at that point minimization and pixel naming is completed iteratively. In this way, by utilizing the graphical structures the co-division of articles given in a lot of pictures should be possible effectively by taking the closer view and foundation of the pictures. What's more, founded on foundation earlier there is usage in hearty item co-division through the Two-Stage Co-Segmentation Scheme [9-11].

Advantages Of Proposed System:

Our proposed system methods are useful in various tasks in computer vision such as image recognition, while in segmentation of objects in a billions of images is too difficult for that our proposed system is used so that the segmentation can be done easily. And the efficiency of our system is very high. The time taking will be less when compared to other models, and the robustness is also very less [12-14].

\section{BLOCK DIAGRAM}

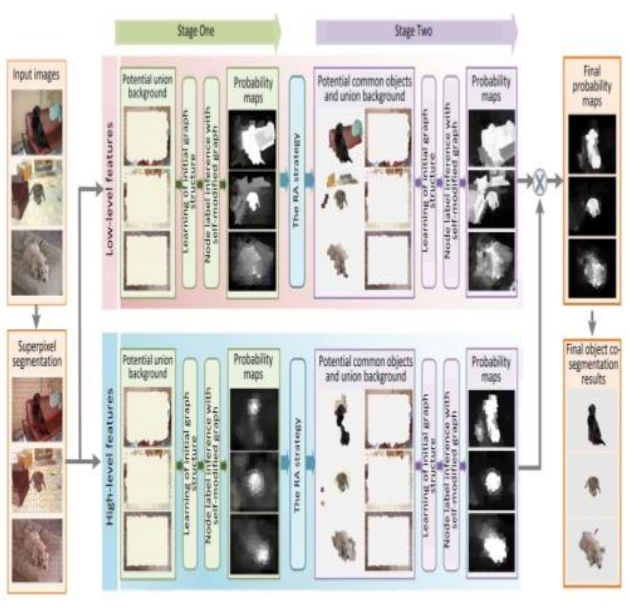




\section{General View Of Image Processing}

Picture preparing is the technique that is to change over a picture into the computerized structure by performing reasonable operations. by applying a few strategies on images then the picture handling is dealt with that pictures as two dimensional and some of the three-dimensional pictures. In picture handling for the most part like to advanced picture preparing yet, there are two increasingly one is optical and the other one is simple. There is an association between PC vision and picture handling is happens while in PC illustrations the pictures are taken from some physical model's and they are changed over into PC vision by picture preparing [15-20].

\section{Steps in Image Processing:}

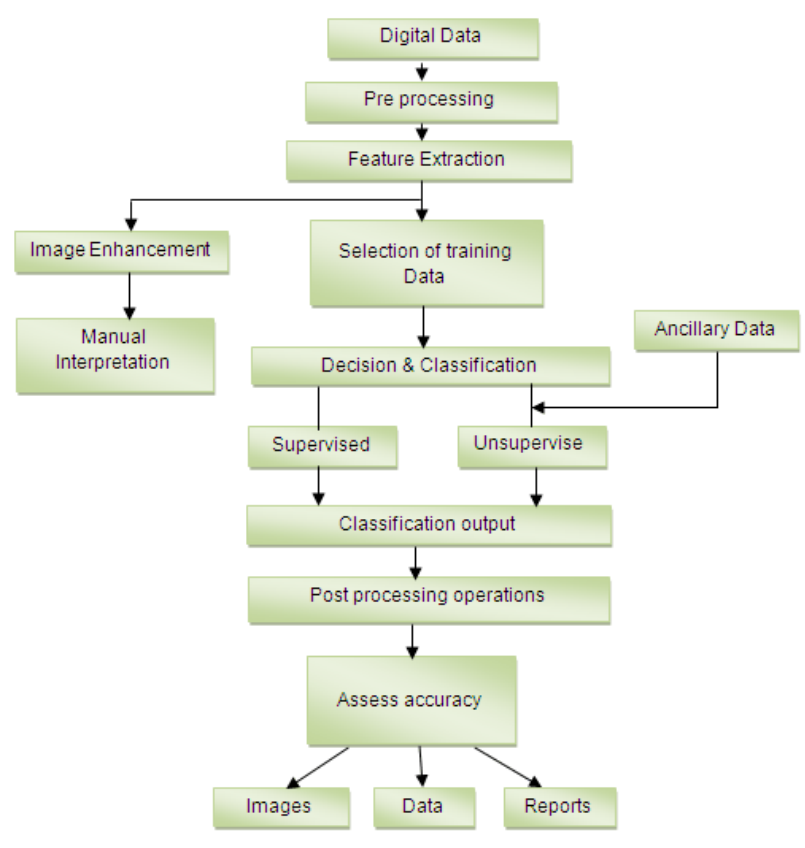

\section{CONCLUSION}

This project stands in first when comapred to other object segmentation in image processing, and through this method there are more than 5000 objects are segmented over a set of images.for the robustness testing, the algorithms which is super pixel segmentation and which seperates the low level and high level features.by the MAT LAB we can learn the graph structures and many image probabililtes.by using that algoritym the segmentation of objects is taken significantly.

\section{REFERENCES}

[1] Kongkham, D. \& Sundararajan, M. 2019, "Distributed wideband sensing method for faded dynamic spectrum access", International Journal of Innovative Technology and Exploring Engineering, vol. 8, no. 10, pp. 4309-4312.

[2] Balaji, S., John Paul Praveen, A. \& Mohanraj, R. 2019, "Recognizable proof and analysis of palm print in biometric authentication system using bayes techniques", International Journal of Innovative Technology and Exploring Engineering, vol. 8, no. 9 Special Issue 3, pp. 1126-1129.

[3] Kavitha, G., Priya, N., Velvizhi, R. \& Allin Geo, A.V. 2019, "Parallel computation in correspondence and signal processing", International Journal of Innovative Technology and Exploring Engineering, vol. 8 , no. 9 Special Issue 3, pp. 1136-1139.
[4] Hema, R., Sundararajan, M. \& Balaji, S. 2019, "Smartphone contro robot with automatic firing gun", International Journal of Innovative Technology and Exploring Engineering, vol. 8, no. 9 Special Issue 3, pp. 625-627.

[5] Kaliyamurthie, K.P., Sundar Raj, B., Velvizhi, R. \& Shanmugapriya K. 2019, "Dual band paper substrate CPW antenna for wireless applications", International Journal of Innovative Technology and Exploring Engineering, vol. 8, no. 9 Special Issue 3, pp. 605-608.

[6] Geo, A.V.A., Arunachalam, A.R., Michael, G. \& Elankavi, R. 2019, "Evaluating architecture using compact modalities", International Journal of Innovative Technology and Exploring Engineering, vol. 8, no. 9 Special Issue 3, pp. 836-838.

[7] Theivasigamani, S., Jeyapriya, D. \& Anita Davamani, K. 2019 , "Anamoly analyzing and exploring for wireless sensor networks", International Journal of Innovative Technology and Exploring Engineering, vol. 8, no. 9 Special Issue 3, pp. 1116-1118.

[8] Jeyapriya, D., Theivasigamani, S., Velvizhi, R. \& Nandhini, P. 2019, "Program detection in wireless feeler networks", International Journal of Innovative Technology and Exploring Engineering, vol. 8, no. 9 Special Issue 3, pp. 1194-1195.

[9] Gowri Sankaran, B., Karthik, B. \& Vijayaragavan, S.P. 2019, "Image compression utilizing wavelet transform", International Journal of Innovative Technology and Exploring Engineering, vol. 8, no. 10, pp. 4305-4308.

[10] Gowri Sankaran, B., Karthik, B. \& Vijayaragavan, S.P. 2019, "Weight ward change region plummeting change for square based image huffman coding", International Journal of Innovative Technology and Exploring Engineering, vol. 8, no. 10, pp. 4313-4316.

[11] Hema, R., Sundararajan, M. \& Balaji, S. 2019, "Smartphone control robot with automatic firing gun", International Journal of Innovative Technology and Exploring Engineering, vol. 8, no. 9 Special Issue 3, pp. 625-627.

[12] Rangaswamy, K. \& Rajabhushanam, C. 2019, "Congestion control in wireless network using TCP friendly rate control (TFRC)", International Journal of Recent Technology and Engineering, vol. 8, no. 2 Special issue 3, pp. 1598-1602.

[13] Tamil Selvan, S. \& Sundararajan, M. 2019, "Performance Parameters of 3 Value 8t Cntfet Based Sram Cell Design Using H-Spice", International Journal of Recent Technology and Engineering, vol. 8 , no. 2 Special issue 5, pp. 22-27.

[14] Vinoth, V.V. \& Kanniga, E. 2019, "Steganographical techniques in hiding text images - system", International Journal of Recent Technology and Engineering, vol. 8, no. 2, pp. 6535-6537.

[15] Saravana, S., Balaji, S., Arulselvi, S. \& John Paul Praveen, A. 2019 "Reliable power quality monitoring and protection system", International Journal of Innovative Technology and Exploring Engineering, vol. 8, no. 9 Special Issue 3, pp. 644-645.

[16] Sundaramoorthy, A. \& John Wiselin, M.C. 2019, "Single patch antenna with multiple feed", International Journal of Innovative Technology and Exploring Engineering, vol. 8, no. 9, pp. 1743-1747.

[17] Velavan, R., Bharanidharan, S. \& Sheeba, B. 2019, "EMF pollution Causes, effects and protection", International Journal of Innovative Technology and Exploring Engineering, vol. 8, no. 9 Special Issue 3, pp. 1166-1168.

[18] Veer, R.A., Arulselvi, S. \& Karthik, B. 2019, "Construction of ensemble square classification approaches in MIMO OFDM", International Journal of Engineering and Advanced Technology, vol. 8, no. 5, pp. 2039-2041.

[19] Agitha, W. \& Kaliyamurthie, K.P. 2019, "Improved energy efficient in WBAN using MAC with cloud computing", International Journal of Innovative Technology and Exploring Engineering, vol. 8, no. 8, pp. 2405-2408.

[20] Kastro, G.G. \& Wiselin, M.C.J. 2019, "Design and analysis of stub loaded resonator", International Journal of Recent Technology and Engineering, vol. 8, no. 1 Special Issue4, pp. 272-283. 


\section{AUTHORS PROFILE}

Balaji. S, Assistant Professor, Department of Electronics and Communication Engineering, Bharath Institute of Higher Education and Research, Chennai, India

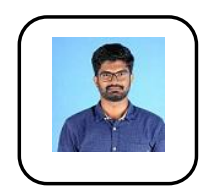

John paul Praveen. Assistant Professor, Department of Electronics and Communication Engineering, Bharath Institute of Higher Education and Research, Chennai, India

B. Hemalatha, Assistant Professor, Department of Electronics and Communication Engineering, Bharath Institute of Higher Education and Research, Chennai, India 